\title{
PENERAPAN MEDIA INTERAKTIF TOLERANSI DAN SUAIAN UNTUK MENINGKATKAN HASIL BELAJAR SISWA PADA PEMBELAJARAN GAMBAR TEKNIK DI SMK NEGERI 6 BANDUNG
}

\author{
Feby R. Gusti ${ }^{1}$, Haryadi ${ }^{2}$, Purnawan $^{3}$ \\ Universitas Pendidikan Indonesia \\ Jl. Dr. Setiabudhi No. 229 Bandung 40154 \\ f.rahmagusti@gmail.com
}

\begin{abstract}
ABSTRAK
Rendahnya hasil belajar siswa pada materi toleransi dan suaian, serta belum optimalnya penggunaan fasilitas komputer sebagai sarana pembelajaran menjadi salah satu pendorong untuk menerapkan media interaktif dalam proses pembelajaran. Penelitian ini bertujuan untuk mengetahui gambaran kemampuan awal siswa, hasil belajar siswa, serta peningkatan hasil belajar siswa pada materi toleransi dan suaian dengan menggunakan media interaktif. Metode yang digunakan pada penelitian ini adalah metode penelitian pre-experiment. Desain penelitian yang digunakan yaitu one group pretest-posttest design. Subyek penelitian adalah siswa kelas XI Teknik Pemesinan di SMK Negeri 6 Bandung dengan jumlah sampel 36 siswa. Peningkatan hasil belajar dinyatakan dalam $\mathrm{N}$-Gain, berdasarkan hasil pre-test dan post-test. Hasil penelitian menunjukkan bahwa kemampuan awal siswa rendah, hasil belajar siswa sedang, serta penerapan media interaktif toleransi dan suaian dapat meningkatkan hasil belajar siswa pada pembelajaran gambar teknik, dimana rata-rata $N$-Gain berkategori sedang.
\end{abstract}

Kata kunci: media interaktif, toleransi dan suaian, hasil belajar

\section{PENDAHULUAN}

Proses pembelajaran dengan menggunakan handout dirasa kurang menarik minat belajar siswa, sehingga menyebabkan siswa tidak memahami materi toleransi dan suaian. Beberapa temuan menunjukkan permasalahan berkaitan dengan proses pembelajaran. Salah satu temuan tersebut adalah mengenai penerapan media berupa handout materi toleransi dan suaian pada mata pelajaran Gambar Teknik di tingkat XI. Hal tersebut memberikan dampak yang merugikan terhadap hasil produksi benda kerja (Asyhar, 2012). Misalnya pembuatan elemen suaian dengan batas ukuran yang tidak sesuai dengan ketentuan daerah toleransi sehingga benda kerja yang dihasilkan tidak sesuai dengan yang direncanakan (reject).

Selain itu, dampak lainnya terlihat pada hasil belajar siswa tingkat XI pada materi toleransi dan suaian yang menunjukkan 90,8\% hasil belajar siswa di bawah KKM yaitu sebesar 76. Besarnya persentase tersebut menunjukkan bahwa pembelajaran dalam kelas termasuk pada kategori belum tuntas. Disamping itu, fasilitas komputer sebagai sarana pembelajaran belum digunakan secara optimal. Penggunaannya hanya sebagai sarana pembelajaran mata pelajaran AutoCAD saja. Hal ini disebabkan belum tersedianya media

\footnotetext{
${ }^{1}$ Mahasiswa Depatemen Pendidikan Teknik Mesin FPTK UPI

${ }^{2}$ Dosen Depatemen Pendidikan Teknik Mesin FPTK UPI

${ }^{3}$ Dosen Depatemen Pendidikan Teknik Mesin FPTK UPI
} 
interaktif untuk diimplementasikan pada perangkat komputer tersebut. Usaha untuk meningkatkan pembelajaran perlu dilakukan, agar ada peningkatan hasil belajar siswa pada pembelajaran gambar teknik dengan menggunakan media interaktif toleransi dan suaian.

Kehadiran media dalam sebuah proses pembelajaran sangat penting untuk menunjang setiap penjelasan yang dijabarkan oleh guru. Media dapat mewakili apa yang kurang mampu guru ucapkan melalui kata-kata atau kalimat tertentu (Dimyati dan Mudjiono, 2006). Dengan adanya media, peserta didik dapat lebih mudah untuk memahami penjelasan mengenai pelajaran. Media apabila dipahami secara garis besar adalah manusia, materi, atau kejadian yang membangun kondisi yang membuat siswa mampu memperoleh pengetahuan, keterampilan, atau sikap (Arsyad, 2014). Dalam pengertian ini, guru, buku teks, dan lingkungan sekolah merupakan media. Media merupakan salah satu komponen komunikasi, yaitu sebagai pembawa pesan dari komunikator menuju komunikan (Daryanto, 2012).

Media merupakan sesuatu yang bersifat menyalurkan pesan dan dapat merangsang pikiran, perasaan, dan kemauan siswa sehingga dapat mendorong terjadinya proses belajar pada dirinya. Dalam proses pembelajaran, media memiliki fungsi sebagai pembawa informasi dari sumber (guru) menuju penerima (siswa) (Krathwohl, 2002). Salah satu fungsi utama media pembelajaran adalah sebagai alat bantu mengajar yang turut mempengaruhi iklim, kondisi, dan lingkungan belajar yang ditata dan diciptakan oleh guru.

Faktor-faktor yang mempengaruhi hasil belajar, antara lain: faktor internal yaitu faktor yang ada dalam diri individu, dan faktor eksternal yaitu faktor yang ada di luar individu (Sugihartono, 2007). Faktor internal meliputi faktor jasmaniah dan psikologis, sedangkan faktor eksternal meliputi faktor keluarga, faktor sekolah, dan faktor masyarakat. Dalam setiap kegiatan belajar-mengajar selalu dilakukan penilaian. Hasil penilaian disajikan dalam bentuk nilai yang berupa angka dan huruf. Pengolahan nilai-nilai menjadi nilai akhir siswa dilakukan dengan mengacu kepada kriteria atau patokan tertentu. Sistem penilaian hasil belajar pada umumnya dibedakan ke dalam dua cara atau dua sistem, yaitu penilaian acuan patokan atau (criterion-referenced evaluation) dan penilaian acuan norma atau (normreferenced evaluation).

\section{METODE PENELITIAN}

Metode yang digunakan adalah metode pre-experiment. Desain penelitian yang digunakan yaitu dengan teknik one group pretest-posttest design. Responden diberi pretest (tes awal), kemudian diberikan treatment (perlakuan), lalu pada akhir pembelajaran diberi posttest (tes akhir). Sampel penelitian dilakukan dengan cara purposive sampling. Populasi 
dalam penelitian ini adalah seluruh siswa kelas XI jurusan Teknik Pemesinan sebanyak 165 siswa. Sampel sebanyak 36 siswa dengan didasarkan apda pertimbangan dari guru mata pelajaran. Instrumen yang digunakan pada penelitian ini adalah test obyektif. Instrumen ini digunakan untuk mengetahui kemempuan atau hasil belajar siswa, dengan mengerjakan soal tentang materi toleransi dan suaian sebanyak 50 butir soal. Instrumen ini mengukur pengetahuan siswa pada ranah kognitif level pengetahuan hingga aplikasi.

Instrumen lain yang digunakan adalah lembar observasi kegiatan pembalajaran, lembar observasi aktivitas siswa, dan angket respon siswa. Lembar observasi kegiatan pembelajaran digunakan untuk memperoleh data mengenai kegiatan yang dilakukan oleh guru dan siswa pada saat proses pembelajaran. Lembar observasi aktivitas siswa digunakan untuk memperoleh data mengenai kegiatan yang dilakukan oleh siswa pada saat proses pembelajaran, sedangkan angket respon siswa digunakan untuk mengetahui respon siswa setelah mempelajari materi toleransi dan suaian menggunakan media interaktif. Analisis data yang digunakan pada penelitian ini adalah teknik analisis statistik. Teknik analisis data yang digunakan yaitu uji normalitas pada hasil pre-test dan post-test, dan uji hipotesis pada data N-Gain.

\section{HASIL PENELITIAN}

Data hasil penelitian menggunakan instrumen berupa tes objektif pilihan ganda berjumlah 42 butir soal dengan 4 opsi pilihan jawaban. Skala penilaian pada penelitian ini menggunakan skala 0-100. Data hasil belajar siswa sebagai parameter penelitian diperoleh dari hasil pre-test dan post-test. Data pre-test dan post-test selanjutnya dapat digunakan untuk menghitung nilai N-Gain. Nilai N-Gain tersebut dapat dijadikan cerminan dari hasil belajar siswa, dan selanjutnya digunakan untuk pengujian hipotesis.

Hasil analisis dan perhitungan yang telah dilakukan menunjukkan bahwa skor tertinggi pre-test sebesar 83,3 dan skor terendah pre-test sebesar 19,05. Kondisi tersebut menunjukkan sebanyak 33 orang siswa (91,7\% siswa) memperoleh nilai di bawah standar KKM (76) dengan rata-rata hasil pretest sebesar 51,52. Artinya kemampuan awal siswa dapat dikatakan rendah.

Nilai pretest tersebut menunjukkan kemampuan awal siswa sebelum dilaksanakan pembelajaran. Hal tersebut dikarenakan siswa belum pernah melaksanakan pembelajaran mengenai materi toleransi dan suaian, sehingga siswa kesulitan dalam menjawab soal-soal tentang materi tersebut. Oleh karena itu, dilakukan treatment pada siswa dengan menggunakan media interaktif toleransi dan suaian. 
Pada penelitian ini siswa diberi perlakuan berupa pembelajaran mengenai materi toleransi dan suaian menggunakan media interaktif, dengan metode semi-individual learning. Dimana setiap siswa secara mandiri mempelajari materi toleransi dan suaian pada satu perangkat komputer yang telah dipasang media interaktif, dan apabila terdapat materi yang kurang dipahami siswa dapat bertanya kepada guru. Setelah pembelajaran dilaksanakan, selanjutnya dilakukan posttest. Adapun data hasil posttest menunjukkan skor tertinggi sebesar 95,24 dan skor terendah sebesar 28,57 dengan rata-rata skor posttest sebesar 66,20 .

Dengan diterapkannya media interaktif toleransi dan suaian, menunjukkan hasil belajar siswa meningkat dengan selisih rata-rata nilai 14,68. Sehingga dapat dikatakan bahwa penerapan media interaktif toleransi dan suaian dapat meningkatkan hasil belajar siswa. Sesuai dengan kerucut pengalaman (cone of experience) model Edgar Dale yang menyatakan bahwa adanya hubungan antara media belajar dengan pengalaman belajar, maka media belajar yang mendekati bentuk kongkret akan meningkatkan pengalaman belajar. Hal tersebut sesuai dengan hasil penelitian yang telah dilakukan, dimana pembelajaran dengan menggunakan media interaktif toleransi dan suaian mampu meningkatkan pengalaman belajar dan hasil belajar siswa.

Kriteria Ketuntasan Minimum (KKM) yang telah ditetapkan untuk mata pelajaran gambar teknik adalah sebesar 76. Hasil pada pelaksanaan pretest terdapat 3 orang siswa $(8,3 \%)$ yang mendapat nilai di atas KKM dan pada pelaksanaan posttest terdapat sebanyak 15 orang siswa $(41,67 \%)$ mendapat nilai di atas KKM. Hal tersebut menunjukkan bahwa penerapan media interaktif toleransi dan suaian dapat meningkatkan hasil belajar siswa. Hasil penelitian ini diperkuat oleh hasil penerapan media pembelajaran berbasis multimedia interaktif secara garis besar dapat meningkatkan hasil belajar siswa ditinjau dari ketuntasan belajar siswa (Masitoh, 2015).

Hasil belajar siswa dipengaruhi oleh faktor internal dan faktor eksternal. Pada penelitian ini, siswa melaksanakan pembelajaran dengan menggunakan media interaktif, dimana setiap siswa melakukan pembelajaran secara semi-individual pada satu perangkat komputer. Media interaktif toleransi dan suaian yang digunakan pada penelitian ini menyajikan materi toleransi dan suaian dalam bentuk teks, gambar dan animasi sehingga dapat menarik minat belajar siswa dan memberikan pengaruh terhadap kemampuan mengingat dan memahami materi. Media interaktif toleransi dan suaian ini juga dapat meningkatkan pengalaman belajar siswa. Semakin konkret proses pembelajaran maka akan semakin baik pengalaman belajar yang dialami sehingga akan meningkatkan hasil belajar 
siswa. Animasi yang terdapat di dalam media interaktif ini memberikan pengalaman tiruan terhadap siswa. Adanya pengaruh positif media interaktif terhadap hasil belajar siswa diperkuat oleh hasil penelitian sebelumnya mengenai studi komparasi antara penggunaan media interaktif dengan media handout. Penggunaan media interaktif dapat meningkatkan hasil belajar siswa menjadi lebih baik dibandingkan dengan menggunakan handout. (Diyanto, 2013).

Setelah diperoleh nilai pretest dan posttest, dilakukan perhitungan nilai N-Gain untuk melihat peningkatan hasil belajar siswa. Nilai N-Gain yang sesuai dengan kriteria penilaian $\mathrm{N}$-Gain diperoleh rata-rata peningkatan hasil belajar sebesar 0,303 dengan kriteria sedang. Terjadi peningkatan hasil belajar siswa dengan kriteria sedang. Hal tersebut menunjukkan bahwa penerapan media interaktif toleransi dan suaian pada pembelajaran gambar teknik dapat memberikan pengaruh yang positif terhadap hasil belajar siswa.

\section{PEMBAHASAN}

Animasi yang terdapat pada media interaktif toleransi dan suaian sangat membantu dalam meningkatkan pemahaman siswa. Dengan animasi tersebut, konsep materi yang bersifat abstrak dapat diubah menjadi lebih konkrit sehingga siswa dapat mengingat dan memahami materi yang disajikan dengan lebih mudah dan cepat (Rohani, 2004). Peningkatan hasil belajar siswa yang berada pada kategori sedang juga tidak terlepas dari kelemahan pada media interaktif maupun pada metode pembelajaran yang dilakukan. Pada media interaktif toleransi dan suaian yang digunakan masih terdapat banyak teks pada tiap halaman tampilannya. Tampilan media dengan banyak teks tersebut kurang menarik minat belajar siswa.

Metode pembelajaran dilakukan secara semi individual dimana siswa belajar secara individu dengan menggunakan perangkat komputer. Apabila terdapat masalah yang kurang dimengerti, maka siswa dapat bertanya kepada guru. Metode belajar semi individual dirasa kurang cocok untuk diterapkan pada pembelajaran gambar teknik khususnya pada materi toleransi dan suaian, karena berdasarkan hasil observasi aktivitas siswa menunjukkan bahwa siswa kurang aktif pada saat pembelajaran berlangsung.

Hasil observasi aktivitas siswa pada saat proses pembelajaran, diperoleh data yang menunjukkan 50,8\% terjadi aktivitas secara positif terhadap proses pembelajaran pada kelas XI TPM 1. Sebanyak 53,8\% terjadi aktivitas secara positif terhadap proses pembelajaran pada kelas XI TPM 2. Hasil observasi guru menunjukan kegiatan pembelajaran tercapai $95 \%$ pada kelas XI TPM 1 dan kegiatan pembelajaran tercapai 100\% pada kelas XI TPM 2. 
Faktor lain yang mempengaruhi adalah waktu pelaksanaan pembelajaran. Dimana sebagian siswa melaksanakan pembelajaran dengan menggunakan media interaktif toleransi dan suaian pada siang hari setelah jam istirahat makan siang dan shalat Dzuhur. Setelah melaksanakan pembelajaran praktik pemesinan. Pada jam tersebut, siswa terlihat kelelahan dan mengantuk sehingga tidak fokus dalam mempelajari materi toleransi dan suaian. Ruang belajar (lab komputer teknik pemesinan) juga menjadi salah satu faktor yang mempengaruhi karena letaknya yang berada di dalam bengkel (workshop) teknik pemesinan. Keadaan ruang belajar yang bising dan panas pada siang hari membuat siswa menjadi tidak fokus.

Penggunaan media interaktif dengan didukung oleh keadaan kelas pada saat pembelajaran berlangsung dapat meningkatkan hasil belajar siswa menjadi lebih baik (Sudjana, 2011). Hasil analisis angket yang disebarkan kepada 36 orang siswa, diperoleh skor sebesar 1554 dari skor maksimum sebesar 2160 dengan persentase angket rata-rata sebesar 71,94\%. Apabila merujuk pada kriteria standar persentase, jika bernilai $>75 \%$, maka termasuk kriteria tinggi. Jika bernilai $61-75 \%$, maka termasuk kriteria sedang dan jika bernilai $<60 \%$ termasuk kriteria rendah (Arikunto, 2010). Sehingga persentase yang diperoleh sebesar 71,94\% termasuk ke dalam kategori sedang.

Hal tersebut dapat dinyatakan bahwa respon siswa terhadap media interaktif toleransi dan suaian adalah positif. Dengan demikian dapat disimpulkan bahwa penerapan media interaktif toleransi dan suaian dapat membuat siswa lebih termotivasi dalam mempelajari materi toleransi dan suaian, serta materi lebih mudah dipahami (Maya, 2011).

\section{KESIMPULAN}

Kesimpulan penelitian ini dapat dirumuskan sebagai berikut: kemampuan awal siswa rata-rata adalah rendah. Hasil belajar siswa dengan menggunakan media interaktif toleransi dan suaian rata-rata berada pada kategori sedang. Peningkatan hasil belajar siswa dengan menggunakan media interaktif toleransi dan suaian rata-rata berada pada kategori sedang.

\section{REFERENSI}

Asyhar, R. (2012). Kreatif mengembangkan media pembelajaran. Jakarta: Referensi.

Arsyad, A. (2014). Media Pembelajaran. Jakarta: RajaGrafindo Persada.

Daryanto. (2012). Media Pembelajaran. Bandung: Sarana Tutorial Nurani Sejahtera.

Dimyati dan Mudjiono. (2006). Belajar dan Pembelajaran. Jakarta: Rineka Cipta. 
Krathwohl, D. R. (2002). A revision of Bloom's taxonomy: an overview. Theory Into Practice, 41(4), p. 212-218.

Masitoh, U. (2015). Penerapan Media Pembelajaran Animasi Sebagai Upaya untuk Meningkatkan Hasil Belajar Mata Kuliah Otomasi. Journal of Mechanical Engineering Education, 2, (1), hlm.145-151.

Maya, A. T. (2011). Media Pembelajaran: Pemilihan Media. Makalah pada FMIPA Universitas Negeri Surabaya, Surabaya.

Rohani, A. (2004). Pengelolaan Pengajaran. Jakarta: Rineka Cipta.

Sudjana, N. (2011). Penilaian Hasil Proses Belajar Mengajar. Bandung: Remaja Rosdakarya.

Sugihartono. (2007). Psikologi Pendidikan. Yogyakarta: UNY Press. 